Accepted ver.

Journal of environmental management. - ISSN 0301-4797. - Vol. 161 (2015): 106-112

doi: 10.1016/j.jenvman.2015.06.038

\title{
THE ENVIRONMENTAL MANAGEMENT PROBLEM OF POHORJE, SLOVENIA: A NEW GROUP APPROACH WITHIN ANP - SWOT FRAMEWORK
}

\author{
Petra Grošelj, Lidija Zadnik Stirn \\ University of Ljubljana, Biotechnical Faculty \\ Jamnikarjeva 101, 1000 Ljubljana, Slovenia \\ petra.groselj@bf.uni-lj.si, lidija.zadnik@bf.uni-lj.si
}

\begin{abstract}
Environmental management problems can be dealt with by combining participatory methods, which make it possible to include various stakeholders in a decision-making process, and multi-criteria methods, which offer a formal model for structuring and solving a problem. This paper proposes a three-phase decision making approach based on the analytic network process and SWOT (strengths, weaknesses, opportunities and threats) analysis. The approach enables inclusion of various stakeholders or groups of stakeholders in particular stages of decision making. The structure of the proposed approach is composed of a network consisting of an objective cluster, a cluster of strategic goals, a cluster of SWOT factors and a cluster of alternatives. The application of the suggested approach is applied to a management problem of Pohorje, a mountainous area in Slovenia. Stakeholders from sectors that are important for Pohorje (forestry, agriculture, tourism and nature protection agencies) who can offer a wide range of expert knowledge were included in the decision-making process. The results identify the alternative of "sustainable development" as the most appropriate for development of Pohorje. The application in the paper offers an example of employing the new approach to an environmental management problem. This can also be applied to decision-making problems in various other fields.
\end{abstract}

Keywords

Analytic network process; Stakeholders; Natural resources; SWOT analysis; Slovenia

\section{Introduction}

Environmental decisions are often complex and include economic, environmental and social value judgments. The objectives of decisions should be clearly stated and can be represented by a set of goals, which should be achieved. The key internal and external factors, which are important to achieving the objectives, should be identified. Possible management strategies should be evaluated regarding various, even conflicting, criteria.

The participation of a number of different stakeholders is necessary in a decision-making process in order to create legitimacy for the final decision (Kangas et al., 2010). Participatory methods are based on public or individual meetings, workshops, surveys, interviews and eparticipation through web platforms and other communication modes. SWOT analysis is an example of a systematic scheme for incorporating internal (strengths and weaknesses) and external (opportunities and threats) factors. The main drawbacks of participatory methods are 
their qualitative orientation and the lack of formal structures and tools for analyzing and interpreting results (Mendoza and Prabhu, 2005). A combination of participatory methods and multi-criteria decision support (MCDS) methods offers a promising approach. Participatory methods and MCDS methods have been widely applied in strategic planning in environmental management problems (Ananda and Herath, 2003; Kiker et al., 2005; Mendoza and Prabhu, 2005; Nordström et al., 2010; Nordström et al., 2009). The main benefit of MCDS methods is the formal model, which assures transparency. Such methods can also help by structuring the problem and making it possible to include conflict, unpredictability, subjectivity and value comparisons on similar scales (Belton and Stewart, 2002). Combining SWOT analysis with MCDS methods led to the development of the A'WOT method (Kurttila et al., 2000), a hybrid of SWOT analysis and an analytic hierarchy process (AHP). AHP is a powerful method for ranking and evaluating objects and can deal with quantitative and qualitative data, including stakeholders' opinions. A'WOT has been applied in a number of applications for ranking SWOT groups and factors (Gallego-Ayala and Juízo, 2011; Kajanus et al., 2004; Kajanus et al., 2012a; Kurttila et al., 2000; Leskinen et al., 2006; Margles et al., 2010; Shinno et al., 2006). An analytic network process (ANP) replaces the hierarchical structure of AHP by applying a network structure which enables more complex interrelations among decision levels and elements. ANP has been used in combination with SWOT analysis only for capturing interdependences amongst SWOT factors (Catron et al., 2013; Sevkli et al., 2012; Wei et al., 2011; Yüksel and Dag`deviren, 2007).

The above-mentioned studies emphasize the identification of advantages and disadvantages. Less attention has been paid to the main objective of the problem. In order to overcome this drawback we suggest the splitting of an objective into strategic goals, which should be attained in order to achieve the objective. In the paper we propose a new approach which integrates SWOT analysis and strategic goals that are essential for achieving the objectives of a decision making process into the ANP network. The proposed approach has three phases and enables inclusion of various stakeholders or groups of stakeholders in particular stages of decision making. Its structure is universal. This enables its application to various problems of environmental management and also to other fields where decision making is required.

In the paper, the developed approach is applied to the problem of the selection of an optimal strategy, based on forestry, agriculture and tourism, for the development of Pohorje, a mountainous region of Slovenia.

The paper is organized as follows. Section 2 presents the revision of the ANP method and the new three-phase approach. Section 3 provides the case study of Pohorje, while Section 4 offers the study's discussion. Section 5 presents the main conclusions.

\section{Methods}

\subsection{Analytic network process}


ANP is an MCDS method for ranking and selecting optimal alternatives according to clusters of goals, criteria and sub-criteria that allows inner dependence between elements within clusters and outer dependence between clusters. The method has a network structure and its main principle is to compare pairs of elements. All elements within a cluster are compared to each other with respect to the element to which they are connected in the control criterion. Judgments in AHP and ANP methods are chosen from a ratio scale from 1 to 9 (Saaty, 2006). Inverse comparisons gain a reciprocal value: $a_{i j}=1 / a_{j i} ; i, j=1, \ldots, n$. All judgments on the same level are gathered in a pairwise comparison matrix $A=\left(a_{i j}\right)_{n \times n}$.

The consistency of comparisons is measured using the consistency index:

$C I_{A}=\frac{\lambda_{A, \max }-n}{n-1}$,

where $\lambda_{A, \max }$ is the maximal eigenvalue of matrix $A$. The consistency index is compared with the random index $R I_{n}$ in the consistency ratio:

$$
C R_{A}=\frac{C I_{A}}{R I_{n}}
$$

According to Saaty (2005b), $C R_{A}<0.1$ signifies acceptably consistent matrix $A$. The priority vector $w=\left(w_{1}, \ldots, w_{n}\right)$ can be derived from the comparison matrix $A$ by the eigenvector method (Saaty, 1980):

$$
A w=\lambda_{\text {max }} w \text {. }
$$

All priority vectors are gathered in an unweighted supermatrix, which provides the relative importance of all clusters. Elements of the unweighted supermatrix are multiplied by the corresponding element in the cluster matrix resulting in a weighted supermatrix. A cluster matrix is a matrix of priority vectors from pairwise comparisons of clusters. Limiting the weighted supermatrix provides a limit supermatrix.

In group AHP or ANP decision making, there are many suitable techniques for aggregating individual judgments or weights (Altuzarra et al., 2007; Bryson and Joseph, 1999; Escobar and Moreno-Jimenez, 2007; Forman and Peniwati, 1998; Grošelj et al., 2011; Hosseinian et al., 2009; Huang et al., 2009; Mikhailov, 2004; Regan et al., 2006; Saaty and Peniwati, 2008). Assuming differences in importance among decision makers, a weighted geometric mean can be applied. The weighted geometric mean can be calculated as

$$
A^{W G M M}=\left(a_{i j}{ }^{(W G M M)}\right)_{n \times n} \text {, with } a_{i j}^{\left({ }^{(W G M M)}\right.}=\prod_{k=1}^{m}\left(a_{i j}^{(k)}\right)^{\alpha_{k}},
$$

where $n$ elements are compared by $m$ decision makers, $A^{\text {WGMM }}$ is the group comparison matrix and $a_{i j}^{(k)}$ and $\alpha_{k}$ are a $k$-th decision maker's judgment and weight respectively.

\subsection{Three-phase approach}


This paper proposes a three-phase decision making approach for evaluating alternatives regarding SWOT groups, SWOT factors and strategic goals. The approach stimulates inclusion of different groups of stakeholders in decision making. The structure of the proposed approach is composed of a network of an objective cluster, a cluster of strategic goals, a cluster of SWOT factors and a cluster of alternatives. Figure 1 shows a schematic representation of an example of the approach with three strategic goals, four SWOT factors within each SWOT group and three alternatives.

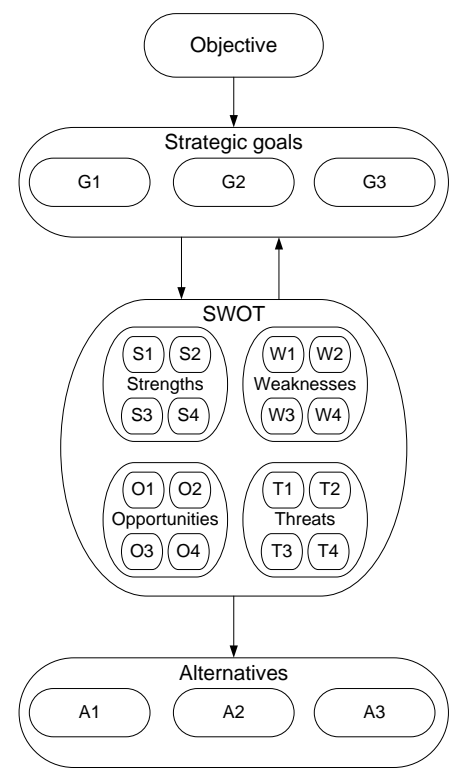

Figure 1: Network structure of the three-phase approach

The procedure of the three-phase approach is presented in Figure 2.

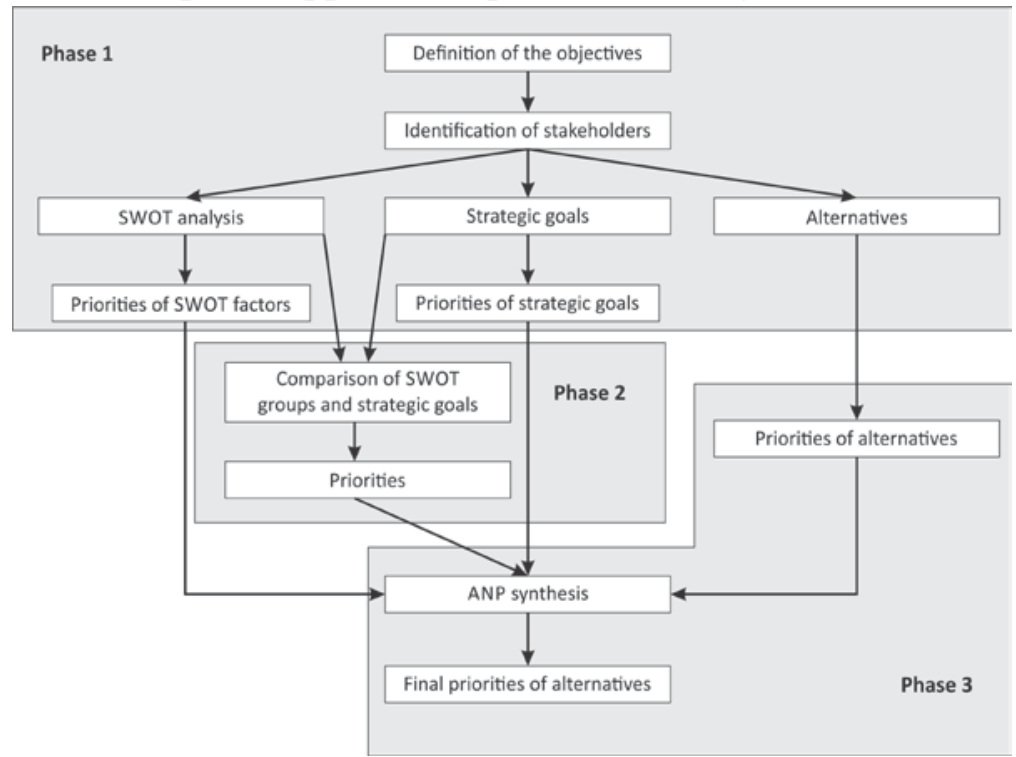

Figure 2: Procedure of the three-phase approach

\subsubsection{Phase 1}

First, the objective of decision making is clearly defined by a leader or a group of leaders. Then, all possible stakeholders (the public sector, government institutions, the private sector, educational institutions, civil associations) should be identified and invited to the decision 
making process. All interested stakeholders should be included in decision making by employing participatory methods. A SWOT analysis for exposing internal and external positive and negative factors, which may affect the objective of the problem, should be preformed. A ranking of strategic factors within SWOT groups should be carried out within the participatory process. This results in priority vectors. Strategic goals, which support the realization of the objective, should be defined. The priority vectors of the strategic goals according to the objective should be derived either within the participatory process or within a smaller, carefully selected group of stakeholders from among all stakeholders by applying the AHP method. Possible alternatives should be identified.

\subsubsection{Phase 2}

The leader or the group of leaders should apply the AHP method to derive the priorities of SWOT groups regarding each strategic goal and the strategic goals for each SWOT group. The importance of clusters of strategic goals and SWOT factors in terms of each SWOT group should be estimated. These weights define the cluster matrix. The leaders of decision making should once again examine the alternatives, determining whether they satisfy all constrains, whether they are realizable and whether they contribute to the attainment of the objective.

\subsubsection{Phase 3}

A group of representative stakeholders is selected to evaluate the alternatives regarding the SWOT factors by employing the AHP method. The stakeholders can be selected from the stakeholders of Phase 1 or from local people. All priority vectors should be gathered in the unweighted supermatrix, the shape of which is presented in Figure 3. The weighted and limit supermatrix should be calculated by applying the ANP method, resulting in the final priorities of alternatives.

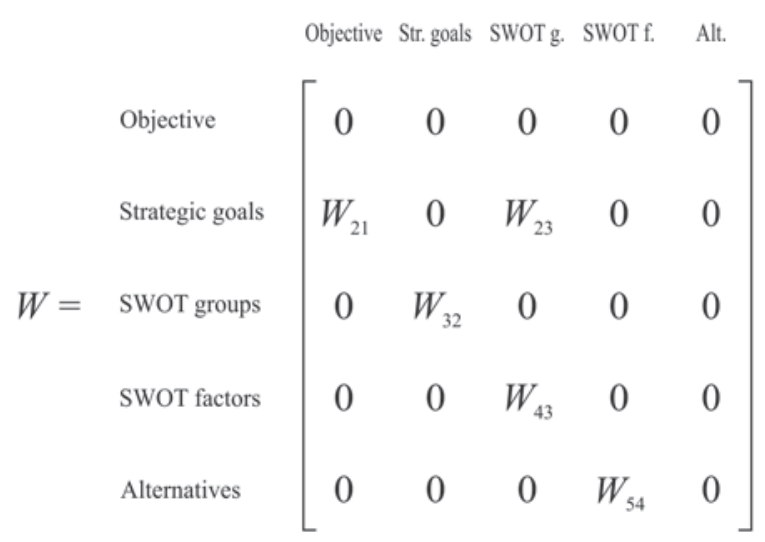

Figure 3: The shape of the supermatrix of the network

\section{CASE STUDY OF POHORJE, SLOVENIA}

The Pohorje region in Slovenia covers an area of $840 \mathrm{~km}^{2}$ (Figure 4). It is considered to be a part of the southeastern alpine region. The area is territorially divided into 16 municipalities and 3 statistical regions. It is a mountainous area under the protection of the alpine convention and most of it is part of Natura 2000. Seventy percent of Pohorje is covered with forests, 
which means that forestry is one of the important economic opportunities in the region. Agriculture presents another economic prospect, as do supplementary activities connected with tourism. The main development of Pohorje is based on tourism. There are several popular recreational centers in Pohorje, with alpine and cross-country skiing offered in winter, and trekking and cycling in summer.

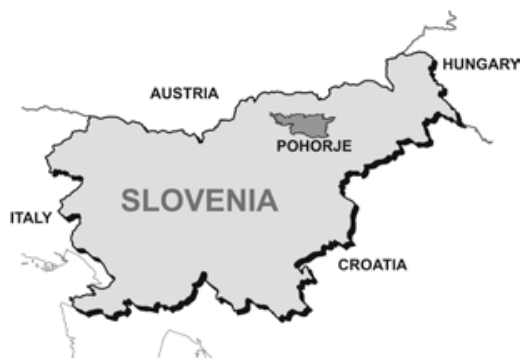

Figure 4: Map showing Pohorje

Our study supplements the NATREG project (NATREG, 2011). The NATREG project was managed by the Institute of the Republic of Slovenia for Nature Conservation. The project's main aim was to acknowledge and promote the potential of natural assets and protected areas as drivers of sustainable regional development and to increase the perception of preserved nature as a valuable asset.

\subsection{Phase 1}

The scope of our study was selecting the optimal strategy for the development of Pohorje. The starting point of the first phase of the decision making approach was studies of the demographic, climatic, geomorphic, ecological and biological characteristics of Pohorje and analysis of forestry, hunting, fishing, agriculture, tourism, water management, nature and environment protection. Natural and cultural heritage were also included (Borec et al., 2010; Cenčič, 2010; Lešnik Štuhec, 2010).

The next step was analysis of stakeholders (Smajić Hodžić, 2010) and selection of the key stakeholders: municipalities, development agencies, chambers, educational institutions, public institutions, institutes, ministries and private entities from the tourism, forestry, agriculture, education, and protection of nature sectors. These stakeholders were invited to the meetings. First, four sector workshops were conducted: two for tourism (11 and 19 stakeholders), one for forestry (19 stakeholders) and one for agriculture (12 stakeholders). The results of workshops are the SWOT analysis of sectors. The joint workshop was attended by 38 stakeholders from different sectors and resulted in a joint SWOT analysis. The elements of the vision have also been formed (Uratarič and Marega, 2010). Each stakeholder was able to select what he or she considered to be the three most important SWOT factors within each SWOT group and evaluated them by assigning 3, 2, or 1 points. For deriving priority vectors and further analysis in the ANP network, the five SWOT factors with the highest number of points within each SWOT group were selected. Their weights were calculated by dividing the number of points of each SWOT factor by the sum of the points of all five SWOT factors within each SWOT group. The results are the local priorities of SWOT factors (1). 


\begin{tabular}{|c|c|c|}
\hline $\begin{array}{l}\text { SWOT } \\
\text { groups }\end{array}$ & SWOT factors & $\begin{array}{c}\text { local } \\
\text { priorities }\end{array}$ \\
\hline \multirow{5}{*}{ Strengths } & Rich cultural and technical heritage & 0.246 \\
\hline & Natural resources (water, wood, stone) & 0.246 \\
\hline & Preservation of nature, wildness, remains of virgin forests, undamaged nature & 0.215 \\
\hline & Climate of Pohorje (clean air), climate resorts & 0.154 \\
\hline & Conditions for a natural park (stoppage of large capital and mega projects) & 0.138 \\
\hline \multirow{5}{*}{ Weaknesses } & $\begin{array}{l}\text { No cooperation in tourism (between tourism suppliers), no integral development } \\
\text { strategy }\end{array}$ & 0.321 \\
\hline & No overall image of Pohorje, no corporate products & 0.250 \\
\hline & $\begin{array}{l}\text { Weak collaboration between sectors (tourism-agriculture, agriculture-forestry, } \\
\text { tourism-forestry) }\end{array}$ & 0.196 \\
\hline & Depopulation of rural areas & 0.125 \\
\hline & Lack of involvement of local people & 0.107 \\
\hline \multirow{5}{*}{ Opportunities } & $\begin{array}{l}\text { Fashion of bio, eco, natural, trends of green tourism (bio food, spending active spare } \\
\text { time, development of new products) }\end{array}$ & 0.386 \\
\hline & Protected products, introduction of new brands - higher prices & 0.175 \\
\hline & Involvement of local people in Pohorje development (production of food) & 0.158 \\
\hline & $\begin{array}{l}\text { Interregional connection of Pohorje and connection with local communities to better } \\
\text { promote the area }\end{array}$ & 0.158 \\
\hline & Aging population - expansion of adopted tourism for them & 0.123 \\
\hline \multirow{5}{*}{ Threats } & Mismatch between sectors, lack of connectivity between institutions, projects, etc. & 0.284 \\
\hline & Mass tourism, mega projects & 0.284 \\
\hline & Abandonment of farms & 0.243 \\
\hline & Unspecified development priorities & 0.122 \\
\hline & No control in tourism & 0.068 \\
\hline
\end{tabular}

A project group consisting of representatives of the Institute of the Republic of Slovenia for Nature Conservation, the Ministry of Environment and Spatial Planning, the Regional Environmental center and Alianta, a company for project consulting formed a "Pohorje 2030" vision (Hojnik, 2011). They also performed brainstorming, which resulted in six strategic goals supporting the realization of the "Pohorje 2030" vision. The vision and the strategic goals were presented to the stakeholders at a regional workshop where the stakeholders could comment on or complement the vision and goals. Five stakeholders who took part in all workshops were selected to pairwise compare the strategic goals regarding their contribution to the realization of the "Pohorje 2030" vision (Grošelj et al., 2013). Their opinions were equally important, and their judgments were aggregated by the geometric mean method (4). The priority vector (Table 2, column Pohorje 2030 vision) was derived from a group comparison matrix using the eigenvector method (3). Super Decisions software (SuperDecisions, 2000) was used to present dependences between clusters and to compute the priority vectors.

\subsection{Phase 2}


Based on the results of the workshops and the project group and in collaboration with representatives of Institute of the Republic of Slovenia for Nature Conservation four possible alternatives for the development of Pohorje, which could be implemented in practice, were defined.

- "Going with the flow" without changes. In other words, retaining the current status quo in Pohorje. Everyone can realize their own ideas with no connection between sectors, suppliers, and local people. All parties try to do their best to realize their goals and ideas regarding contributing to Pohorje development, achieving their own success (tourism) or improving their existence (agriculture).

- "Sustainable development”, which considers regional peculiarities and natural resources and assures their sustainability. Agriculture and timber production is not particularly intensive and it is sustainable. Tourism, which is sustainable and preserves nature, offers visitors active recreational activities, holidays and opportunities to participate in sports and spend time in nature. It preserves cultural and natural heritage. Ensuring a high quality of life for local people is important, as they can contribute to the development of Pohorje.

- "Intensive sectoral development", which emphasizes intensive use of natural resources, tourism and industry. All economic opportunities should be exploited timber, peat, water, electricity, and non-timber products. Small enterprise opportunities are stimulated and modern family farms are suitable.

- “Conservation of nature”. Nature should be protected and everything connected with "green” is stressed. Preservation of nature and biodiversity are most important and sustainable tourism and ecological agriculture is possible. Education about nature and cultural heritage is important. Park Pohorje and a fund for nature preservation will be established.

Appendix A1 of Supplementary Material provides the network structure of the problem.

Table 2: Priorities of strategic goals with respect to "Pohorje 2030" vision and with respect to SWOT groups

\begin{tabular}{l|c|ccrr}
\hline & $\begin{array}{c}\text { Pohorje 2030 } \\
\text { vision }\end{array}$ & strengths & weaknesses & opportunities & threats \\
\hline High quality life of locals & 0.162 & 0.081 & 0.087 & 0.087 & 0.087 \\
$\begin{array}{l}\text { Preserved nature and country } \\
\text { Sustainable tourism and limited visits }\end{array}$ & 0.163 & 0.258 & 0.243 & 0.243 & 0.243 \\
$\begin{array}{l}\text { Environmental and consumer friendly } \\
\text { usage of natural resources }\end{array}$ & 0.181 & 0.156 & 0.110 & 0.139 & 0.139 \\
$\begin{array}{l}\text { Environmental and consumer friendly } \\
\text { mobility and good infrastructure }\end{array}$ & 0.131 & 0.123 & 0.176 & 0.176 & 0.110 \\
$\begin{array}{l}\text { Preserved cultural heritage and local } \\
\text { tradition }\end{array}$ & 0.205 & 0.245 & 0.243 & 0.243 & 0.243 \\
\hline
\end{tabular}


Pairwise comparisons of strategic goals with respect to each SWOT group and SWOT groups with respect to each strategic goal were performed by one of the leaders of the NATREG project from Institute of the Republic of Slovenia for Nature Conservation. The priority vectors (Table 2, Table 3) were derived from comparison matrices by the eigenvector method (3).

Table 3: Priorities of SWOT groups with respect to Strategic goals

\begin{tabular}{lcccccc}
\hline & $\mathrm{s} 1$ & $\mathrm{~s} 2$ & $\mathrm{~s} 3$ & $\mathrm{~s} 4$ & $\mathrm{~s} 5$ & $\mathrm{~s} 6$ \\
\hline strengths & 0.451 & 0.363 & 0.460 & 0.451 & 0.391 & 0.423 \\
weaknesses & 0.119 & 0.148 & 0.161 & 0.169 & 0.195 & 0.174 \\
opportunities & 0.261 & 0.326 & 0.258 & 0.261 & 0.276 & 0.266 \\
threats & 0.169 & 0.163 & 0.122 & 0.119 & 0.138 & 0.137 \\
\hline
\end{tabular}

\subsection{Phase 3}

For evaluation of alternatives regarding SWOT factors, twelve stakeholders were selected. They were experts - three from each of the fields of forestry, agriculture, tourism, and nature protection - who knew Pohorje well and participated in the NATREG project. Surveys were carried out in individual meetings so that the particularities of the AHP method could be explained and so that all the stakeholders' questions could be immediately answered. The stakeholders had some difficulties achieving an acceptable consistency of matrices. If $\mathrm{CR}>0.1$, stakeholders were advised to adopt their judgments. Because the initial consistency ratios were much higher than 0.1 in some cases, we decided to allow $\mathrm{CR}<0.15$. This adoption did not change the final results, but it did help the stakeholders significantly.

First, the experts were asked to pairwise compare the four above-mentioned sectors in order to establish which sectors were more important for decision making regarding the development of Pohorje. To aggregate individual judgments in this stage, we presumed that all stakeholders were equally important with weights $\alpha_{k}=1 / 12, k=1, \ldots, 12$, and we used the geometric mean method (4). The results were the weights of the sectors. To calculate the individual importance weightings, we presumed that the stakeholders within each sector were equally important (Table 4).

\begin{tabular}{lc}
\multicolumn{1}{c}{ Table 4: Weightings of stakeholders’ importance } \\
\hline \multicolumn{1}{c}{ stakeholders } & weight \\
\hline stakeholders - tourism & 0.0814 \\
stakeholders - forestry & 0.0759 \\
stakeholders - agriculture & 0.0807 \\
stakeholders - nature protection & 0.0953 \\
\hline
\end{tabular}

In the second step, the stakeholders were asked to pairwise compare the four alternatives according to each SWOT factor. The weighted geometric mean method was applied for aggregating individual judgments using weights from Table 6 as $\alpha_{k}, k=1, \ldots, 12$. The derived priority vectors together with priority vectors from Tables 2, 3, and 4 were gathered in an unweighted supermatrix (Appendix A2 of Supplementary Material). 
Priorities in blocks $W_{23}$ and $W_{43}$ of the unweighted supermatrix (Figure 3) were multiplied by 0.5 because it was estimated that the clusters strategic goals and SWOT factors are equally important with respect to SWOT groups. The result was the weighted supermatrix. Super Decisions software (SuperDecisions, 2000) was used for deriving the limit supermatrix. The final result of the alternative ranking is presented in Table 5.

\begin{tabular}{lcc}
\multicolumn{3}{l}{ Table 5: Final priorities of alternatives of Pohorje development. } \\
\hline Alternatives & Final priorities & Rank \\
\hline Going with the flow & 0.122 & 4 \\
Sustainable development & 0.576 & 1 \\
Intensive sectoral development & 0.125 & 3 \\
Conservation of nature & 0.177 & 2 \\
\hline
\end{tabular}

\section{Discussion}

The results indicate that sustainable development is the only possible and logical alternative for managing Pohorje. This approach takes advantage of strengths and opportunities and tries to avoid weaknesses and threats. Intensive sectoral development over-stresses short-term economic development and does not sufficiently emphasize the protection of nature. Conservation of nature, on the other hand, overly stresses the protection of nature and does not sufficiently emphasize economic development. Adhering to the status quo (alternative going with the flow) is not a very effective alternative, as the stakeholders may have already seen in Pohorje. If all stakeholders, despite their varying views, could reach a consensus, as it appears they did based on their final decision, then it should be easier to implement the changes in practice.

The stakeholders who evaluated the alternatives have not been equally important. The field of nature protection received the greatest weight, indicating that stakeholders believe that the opinion of experts from the field of nature protection is important since the experts strive to maintain nature and the biodiversity of Pohorje.

The final results are based on the ranking of SWOT factors and strategic goals. The most important strengths are "rich cultural and technical heritage" and "natural resources" while the biggest weakness is "no cooperation in tourism". The greatest weighting of all strategic factors belongs to the "fashion of the bio, eco, natural trend of green tourism" opportunity. The "mismatch between sectors and lack of connectivity between institutions and projects" represents the largest threat for the development of Pohorje. The difference between the first ranked and last ranked strategic goals is only seven percent, which emphases the importance of fulfilling all strategic goals in order to realize the "Pohorje 2030" vision.

SWOT analysis is a widely used tool for evaluation of strengths, weaknesses, opportunities and threats regarding a problem. Its employment within the AHP or ANP method enables a ranking of SWOT factors and a comparison of alternatives regarding SWOT factors (Kajanus et al., 2012a). We used that model as a basis of our new approach as we wanted to focus on 
the objective of a decision-making problem. To attain this goal, we propose defining strategic goals, which contribute to an objective. Our approach incorporates strategic goals and SWOT analysis in the ANP model. The represented application shows the application of this approach to a real-world problem.

Validation of AHP model is an important issue. Due to the qualitative and quantitative factors and subjective judgments of the stakeholders it is not possible to compare the results with the data from different case studies. Despite this difficulty the suitability of AHP/ANP model for complex decisions has been thoroughly validated (Ishizaka et al., 2011; Saaty, 2005a). The validation of pairwise comparison matrices within ANP model was made by their consistency ratio (2).

Wide use of SWOT analysis combined with AHP/ANP method promises its appropriateness in strategic planning situations (Kajanus et al., 2012b). The incorporation of strategic goals in the model enables the decision makers easier focus on the objective of the problem which should improve the decision making process.

The proposed three phase approach enables inclusion of different stakeholders in different phases which allows stakeholders relevant to the specific environmental problem to be included and thus increases the benefits of participation (Reed, 2008).

Aggregation of individual judgments belonging to possibly heterogeneous group of stakeholders from environmental connected fields is another important topic that should be addressed (Marchamalo and Romero, 2007; Srdjevic et al., 2013). We selected weighted geometric mean method which is understandable and transparent for stakeholders and has demonstrated its suitability through many applications (Ananda and Herath, 2008; CortésAldana et al., 2009; Duke and Aull-Hyde, 2002; Lee et al., 2009; Srdjevic et al., 2013; Sun and Li, 2009; Wang and Chin, 2009).

The final results of the case study were presented to the stakeholders from Phase 3 and they agreed that the results express their opinions.

\section{Conclusions}

Environmental management should take into account a wide range of different topics like economic issues, ecological concerns, natural resource management and the inclusion of local people. Problems faced in environmental management are often complex and multidisciplinary and their handling requires the inclusion of various stakeholders in the decision making process. The AHP framework in combination with SWOT analysis is a suitable tool that can handle such problems. This paper proposes a new, three-phase approach based on the integration of strategic goals and SWOT analysis in the ANP framework. It also enables the inclusion of various groups of stakeholders in decision making. 
In the first phase, the definition of the problem and the identification of stakeholders are required. SWOT analysis and the definition of strategic goals contributing to the main objective should be carried out with the cooperation with stakeholders. A ranking of SWOT factors regarding SWOT groups and of strategic goals regarding the objective should be performed. We propose the application of the weighted geometric mean method for aggregation of individual judgments within the AHP method. The first stage of the identification of alternatives should be carried out by the stakeholders. The second phase involves the evaluation of dependencies between SWOT groups and strategic goals. Identification of the alternatives should be finalized. In the third phase, stakeholders compare alternatives regarding SWOT factors. The final results are developed by a standard ANP synthesis.

The new approach was applied to a management problem of Pohorje, Slovenia. The Pohorje case represents a protected area that is facing a number of competing demands and is of interest to a wide range of stakeholders. The results confirm that sustainable development is the only proper and desirable alternative for the development of Pohorje.

The proposed approach could be applied to similar problems in environmental management and also to problems in various other fields. Further research should investigate the replacement of classical ANP with fuzzy ANP, which could enable dealing with non-precise judgments.

\section{Acknowledgement}

The authors are grateful to Dr. Darij Krajčič and Gregor Danev from The Institute of the Republic of Slovenia for Nature Conservation for all data from the NATREG project.

The authors acknowledge financial support from Slovenian Research Agency within the framework of Program P4-0059.

\section{References}

Altuzarra, A., Moreno-Jiménez, J.M., Salvador, M., 2007. A Bayesian priorization procedure for AHP-group decision making. European Journal of Operational Research 182, 367-382.

Ananda, J., Herath, G., 2003. The use of Analytic Hierarchy Process to incorporate stakeholder preferences into regional forest planning. Forest Policy and Economics 5, 13-26.

Ananda, J., Herath, G., 2008. Multi-attribute preference modelling and regional land-use planning. Ecological Economics 65, 325-335.

Belton, V., Stewart, T.J., 2002. Multiple Criteria Decision Analysis: An integrated approach. Kluwer Academic Publishers, Norwell, MA.

Borec, A., Jež, A., Bohak, Z., 2010. Stanje kmetijstva na projektnem območju Pohorje [The state of agriculture in the project area Pohorje]; project: NATREG. 61. http://www.zrsvn.si/dokumenti/64/2/2010/NATREG_vsebina_studije_1972.pdf. 9. 5. 2012. 
Bryson, N., Joseph, A., 1999. Generating consensus priority point vectors: a logarithmic goal programming approach. Computers \& Operations Research 26, 637-643.

Catron, J., Stainback, G.A., Dwivedi, P., Lhotka, J.M., 2013. Bioenergy development in Kentucky: A SWOT-ANP analysis. Forest Policy and Economics 28, 38-43.

Cenčič, L., 2010. Stanje gozdov in divjadi ter gozdarstva in lovstva na projektnem območju Pohorje [State of forests and wildlife, forestry and hunting in the project area Pohorje]; project: NATREG. 54. http://www.natreg.eu/pohorje/uploads/datoteke/Studija\%20Gozdarstvo_Pohorje.pdf. 9. 5. 2012.

Cortés-Aldana, F.A., García-Melón, M., Fernández-de-Lucio, I., Aragonés-Beltrán, P., Poveda-Bautista, R., 2009. University objectives and socioeconomic results: A multicriteria measuring of alignment. European Journal of Operational Research 199, 811-822.

Duke, J.M., Aull-Hyde, R., 2002. Identifying public preferences for land preservation using the analytic hierarchy process. Ecological Economics 42, 131-145.

Escobar, M.T., Moreno-Jimenez, J.M., 2007. Aggregation of individual preference structures in AHP-group decision making. Group Decision and Negotiation 16, 287-301.

Forman, E., Peniwati, K., 1998. Aggregating individual judgments and priorities with the analytic hierarchy process. European Journal of Operational Research 108, 165-169.

Gallego-Ayala, J., Juízo, D., 2011. Strategic implementation of integrated water resources management in Mozambique: An A'WOT analysis. Physics and Chemistry of the Earth, Parts A/B/C 36, 1103-1111.

Grošelj, P., Pezdevšek Malovrh, Š., Zadnik Stirn, L., 2011. Methods based on data envelopment analysis for deriving group priorities in analytic hierarchy process. Central European Journal of Operations Research 19, 267-284.

Grošelj, P., Zadnik Stirn, L., Danev, G., Krajčič, D., 2013. Ranking strategic and operative goals for sustainable development of Pohorje, Slovenia. Acta Silvae et Ligni 100, 47-55.

Hojnik, M., 2011. Vizija območja - Pohorje 2030; projekt: NATREG. http://www.natreg.eu/pohorje/uploads/datoteke/1_1\%20VIZIJA\%20OBMOCJA\%20-

\%20POHORJE\%202030.pdf. 9. maj 2012.

Hosseinian, S., Navidi, H., Hajfathaliha, A., 2009. A New Linear Programming Method for Weights Generation and Group Decision Making in the Analytic Hierarchy Process. Group Decision and Negotiation 21, 1-22.

Huang, Y.S., Liao, J.T., Lin, Z.L., 2009. A Study on Aggregation of Group Decisions. Systems Research and Behavioral Science 26, 445-454.

Ishizaka, A., Balkenborg, D., Kaplan, T., 2011. Does AHP help us make a choice? An experimental evaluation. J Oper Res Soc 62, 1801-1812.

Kajanus, M., Kangas, J., Kurttila, M., 2004. The use of value focused thinking and the A’WOT hybrid method in tourism management. Tourism Management 25, 499-506.

Kajanus, M., Leskinen, P., Kurttila, M., Kangas, J., 2012a. Making use of MCDS methods in SWOT analysis-Lessons learnt in strategic natural resources management. Forest Policy and Economics 20, 1-9. 
Kajanus, M., Leskinen, P., Kurttila, M., Kangas, J., 2012b. Making use of MCDS methods in SWOT analysis-Lessons learnt in strategic natural resources management. Forest Policy and Economics 20, 1-9.

Kangas, A., Saarinen, N., Saarikoski, H., Leskinen, L.A., Hujala, T., Tikkanen, J., 2010. Stakeholder perspectives about proper participation for Regional Forest Programmes in Finland. Forest Policy and Economics 12, 213-222.

Kiker, G.A., Bridges, T.S., Varghese, A., Seager, T.P., Linkov, I., 2005. Application of multicriteria decision analysis in environmental decision making. Integrated Environmental Assessment and Management 1, 95-108.

Kurttila, M., Pesonen, M., Kangas, J., Kajanus, M., 2000. Utilizing the analytic hierarchy process (AHP) in SWOT analysis -- a hybrid method and its application to a forestcertification case. Forest Policy and Economics 1, 41-52.

Lee, A.H.I., Chang, H.-J., Lin, C.-Y., 2009. An evaluation model of buyer-supplier relationships in high-tech industry - The case of an electronic components manufacturer in Taiwan. Computers \& Industrial Engineering 57, 1417-1430.

Leskinen, L.A., Leskinen, P., Kurttila, M., Kangas, J., Kajanus, M., 2006. Adapting modern strategic decision support tools in the participatory strategy process-a case study of a forest research station. Forest Policy and Economics 8, 267-278.

Lešnik Štuhec, T., 2010. Predstavitev Pohorja in posnetek stanja turizma in s turizmom povezanih dejavnosti [Presentation of Pohorje and a snapshot of tourism and tourism-related activities]; project: NATREG.

www.natreg.eu/pohorje/.../20101123_Turizem\%20I_faza_povzetek.pdf. 9. 5. 2012.

Marchamalo, M., Romero, C., 2007. Participatory decision-making in land use planning: An application in Costa Rica. Ecological Economics 63, 740-748.

Margles, S.W., Masozera, M., Rugyerinyange, L., Kaplin, B.A., 2010. Participatory Planning: Using SWOT-AHP Analysis in Buffer Zone Management Planning. Journal of Sustainable Forestry 29, 613-637.

Mendoza, G.A., Prabhu, R., 2005. Combining participatory modeling and multi-criteria analysis for community-based forest management. Forest Ecology and Management 207, 145-156.

Mikhailov, L., 2004. Group prioritization in the AHP by fuzzy preference programming method. Computers \& Operations Research 31, 293-301.

NATREG, 2011. NATREG: Managing Natural Assets and Protected Areas as Sustainable Regional Development Opportunities http://www.natreg.eu/pohorje/. 10. 2. 2012.

Nordström, E.-M., Eriksson, L.O., Öhman, K., 2010. Integrating multiple criteria decision analysis in participatory forest planning: Experience from a case study in northern Sweden. Forest Policy and Economics 12, 562-574.

Nordström, E.-M., Romero, C., Eriksson, L.O., Ohman, K., 2009. Aggregation of preferences in participatory forest planning with multiple criteria: an application to the urban forest in Lycksele, Sweden. Canadian Journal of Forest Research 39, 1979-1992. 
Reed, M.S., 2008. Stakeholder participation for environmental management: A literature review. Biological Conservation 141, 2417-2431.

Regan, H.M., Colyvan, M., Markovchick-Nicholls, L., 2006. A formal model for consensus and negotiation in environmental management. Journal of Environmental Management 80, 167-176.

Saaty, T., 2005a. Making and validating complex decisions with the AHP/ANP. J. Syst. Sci. Syst. Eng. 14, 1-36.

Saaty, T.L., 1980. The Analytic Hierarchy Process. McGraw-Hill, New York.

Saaty, T.L., 2005b. Theory and Applications of the Analytic Network Process: Decision Making with Benefits, Opportunities, Costs, and Risks. RWS Publications, Pittsburgh.

Saaty, T.L., 2006. Fundamentals of Decision Making and Priority Theory with the Analytic Hierarchy Process. RWS Publications, Pittsburgh.

Saaty, T.L., Peniwati, K., 2008. Group decision making: Drawing out and reconciling differences. RWS Publications, Pittsburgh, PA.

Sevkli, M., Oztekin, A., Uysal, O., Torlak, G., Turkyilmaz, A., Delen, D., 2012. Development of a fuzzy ANP based SWOT analysis for the airline industry in Turkey. Expert Systems with Applications 39, 14-24.

Shinno, H., Yoshioka, H., Marpaung, S., Hachiga, S., 2006. Quantitative SWOT analysis on global competitiveness of machine tool industry. Journal of Engineering Design 17, 251-258.

Smajić Hodžić, A., 2010. Analiza deležnikov na pilotnem območju Pohorje - Skupno poročilo, projekt: NATREG. Zavod RS za varstvo narave, Ljubljana, p. 17.

Srdjevic, Z., Lakicevic, M., Srdjevic, B., 2013. Approach of Decision Making Based on the Analytic Hierarchy Process for Urban Landscape Management. Environmental Management 51, 777-785.

Sun, J., Li, H., 2009. Financial distress early warning based on group decision making. Computers \& Operations Research 36, 885-906.

SuperDecisions, 2000. Super Decisions. http://www.superdecisions.com.

Uratarič, N., Marega, M., 2010. Poročilo z zaključne delavnice za izdelavo analize SWOT in oblikovanje elementov vizije [Report of the final workshop of a SWOT analysis and design elements of the vision]; project: NATREG. Regional environmental center, Maribor, p. 18.

Wang, Y.-M., Chin, K.-S., 2009. A new data envelopment analysis method for priority determination and group decision making in the analytic hierarchy process. European Journal of Operational Research 195, 239-250.

Wei, W., Xin, D., Zongming, L., 2011. Analysis of the cumulative effect of pollution in the atmospheric environment management based on the method of ANP embedding into SWOT, 2011 International Conference on Remote Sensing, Environment and Transportation Engineering (RSETE), pp. 65-68.

Yüksel, İ., Dag deviren, M., 2007. Using the analytic network process (ANP) in a SWOT analysis - A case study for a textile firm. Information Sciences 177, 3364-3382. 